\title{
Allantoin excretion in the rat
}

\author{
By NELLY PAK, G. DONOSO* AND MARIA A. TAGLE \\ Basic Nutrition Unit, Department of Nutrition, Faculty of Medicine, \\ University of Chile, Santiago, Chile
}

(Received 21 August 1972-Accepted I8 Ganuary 1973)

\begin{abstract}
I. Allantoin excretion was determined in forty-four rats; twenty-four rats were $\mathbf{2} \mathrm{d}$ old and twenty were $90 \mathrm{~d}$ old. The animals received ad lib. for I I d diets that contained varying amounts of protein from casein and from gluten. Urinary allantoin excretion was determined during the last $3 \mathrm{~d}$ of the period.

2. The amount of allantoin excreted in both young and adult animals was independent of the diet consumed and was related to metabolic weight ( $W$ in $\mathrm{kg}^{\mathbf{0}}{ }^{\mathbf{3}}$ ) and rate of gain in bodyweight $(\triangle \mathrm{W}$ in $\mathrm{g} / \mathrm{d})$, also to body nitrogen content $\left(\mathrm{N}\right.$ in $\left.\mathrm{g}^{0 \cdot 73}\right)$ and rate of gain in body $\mathrm{N}$ ( $\triangle N$ in $\mathrm{mg} / \mathrm{d}$ ), according to the equations allantoin $(\mathrm{mg} / \mathrm{d})=60.54 \mathrm{~W}^{0 \cdot 73}+2 \cdot 12 \Delta \mathrm{W}$, and allantoin $(\mathrm{mg} / \mathrm{d})=5.45 \mathrm{~N}^{0.79}+0.07 \mathrm{I} \triangle \mathrm{N}$.
\end{abstract}

When nucleic acids are catabolized by the rat, most of the purine moiety is excreted in the urine as allantoin. The amount excreted has been found to be higher under physiological conditions associated with increased protein synthesis such as pregnancy and lactation (Morgan \& Hanson, I964). Other investigators (Kiriyama \& Ashida, I964) suggested that allantoin excretion is a complex function of body size and rate of growth and that it is also affected by the age of the animal and the quality of the dietary protein. However, no attempt has been made to determine quantitatively the excretion of allantoin as a function of these variables.

We have examined allantoin excretion in very young and in adult rats fed on different diets and obtained two equations that can predict the allantoin excretion from the metabolic body-weight and the gain in body-weight, and from the body nitrogen content and the gain in body $\mathrm{N}$.

\section{EXPERIMENTAL}

\section{Main trial}

Allantoin excretion was measured in forty-four rats; twenty-four were $2 \mathrm{I} d$ old and twenty were $90 \mathrm{~d}$ old. The young rats were divided into six groups of four; the adult rats were divided into three groups of four, two groups of three and one group of two (see Table 2). The animals were housed individually in metabolic cages and each of the six groups of young rats and each of the six groups of old rats was given a different diet (see Tables $I$ and 2). The first five diets contained, in terms of ratio of energy supplied by utilizable protein to total metabolizable energy (NDp:E), 0.04, $0.08,0.2$, 0.4 or 0.6 protein energy from casein, and the 6 th diet 0.2 protein energy from gluten. All the diets were prepared as described by Tagle $\&$ Donoso (1967). They consisted of maize starch, vegetable oil, minerals and vitamins, and protein (casein or gluten) replacing part of the starch. The rats were weighed daily, urine was collected during

* Present address: ODEPLAN, Huérfanos I202, Santiago, Chile. 
the last $3 \mathrm{~d}$ of an I $\mathrm{d}$ period and allantoin was estimated in the $3 \mathrm{~d}$ samples by the procedure of Young \& Conway (I942). The rats were killed and individually analysed for $\mathrm{N}$ by the method of Kjeldhal using a Markham (1942) apparatus.

In addition, ten $2 \mathrm{I}-\mathrm{d}$-old and ten $90-\mathrm{d}$-old rats were killed at the beginning of the trial and their carcasses were analysed for $\mathrm{N}$. The mean amount of $\mathrm{N}$ found in these groups was used to calculate the initial $\mathrm{N}$ content of the young and adult rats used in the feeding experiment.

\section{Supplementary trial}

Sixteen rats, $3^{1} \mathrm{~d}$ old, were fed, ad lib., during II $\mathrm{d}$ on a non-protein diet. The non-protein diet was used to induce coprophagy. The animals were divided into two groups: eight (mean weight $70.5 \mathrm{~g}$ ) in which coprophagy was prevented by means of a double belt system (Araya, Araya \& Tagle, 1971), and eight (mean weight $70.6 \mathrm{~g}$ ) for which coprophagy was allowed. All the animals were individually housed in metabolic cages, and faeces were collected during the last $3 \mathrm{~d}$. Faecal RNA concentration was determined in the samples by the procedure of Di Carlo \& Schultz (1948).

\section{RESULTS}

\section{Main trial}

The experimental values for initial body-weight, rate of body-weight gain, initial body $\mathrm{N}$ content and rate of body $\mathrm{N}$ gain for the various diets, together with the experimental and predicted values for allantoin excretion are shown in Table I, for young rats, and in Table 2 , for adult rats.

Allantoin excretion was found, as expected (Tagle \& Donoso, 1965), to be related to total protein synthesis necessary for maintenance and growth. The allantoin excretion could be expressed either as a function of weight and weight gain or as a function $o$ body $\mathrm{N}$ and body $\mathrm{N}$ gain.

The following equations were obtained:

$$
\begin{aligned}
& \text { Allantoin }(\mathrm{mg} / \mathrm{d})=60 \cdot 54 \mathrm{~W}^{0.73}+2 \cdot 12 \Delta \mathrm{W}, \\
& \text { Allantoin }(\mathrm{mg} / \mathrm{d})=5.45 \mathrm{~N}^{0.73}+0.07 \mathrm{I} \Delta \mathrm{N},
\end{aligned}
$$

where $\mathrm{W}$ is the body-weight (in $\mathrm{kg}$ ) at the roth day (middle of urine collection period), $\Delta W$ is the mean body-weight gain (g/d) over II d, N is the body $N(g)$ at the roth day and $\Delta \mathrm{N}$ is the mean body $\mathrm{N}$ gain $(\mathrm{mg} / \mathrm{d})$ over II $\mathrm{d}$.

The constants in the equations were obtained by plotting individual values of allantoin $\div \Delta \mathrm{W}$ against $\mathrm{W}^{0} \cdot 73 \div \Delta \mathrm{W}$ for equation $(a)$ and by similarly plotting allantoin $\div \Delta \mathrm{N}$ against $\mathrm{N}^{0 \cdot 73} \div \Delta \mathrm{N}$ for equation $(b)$. In each instance a good linear relation was obtained. The correlation coefficient of relation $(a)$ was +0.98 and for relation $(b)$ it was +0.99 , even though both young and adult rats given different diets were included. In both $(a)$ and $(b)$, the first term on the right probably represents the excretion of allantoin derived from protein synthesis associated with maintenance of body proteins and the second term might be associated with allantoin produced during synthesis of new tissues. 
Vol. 30

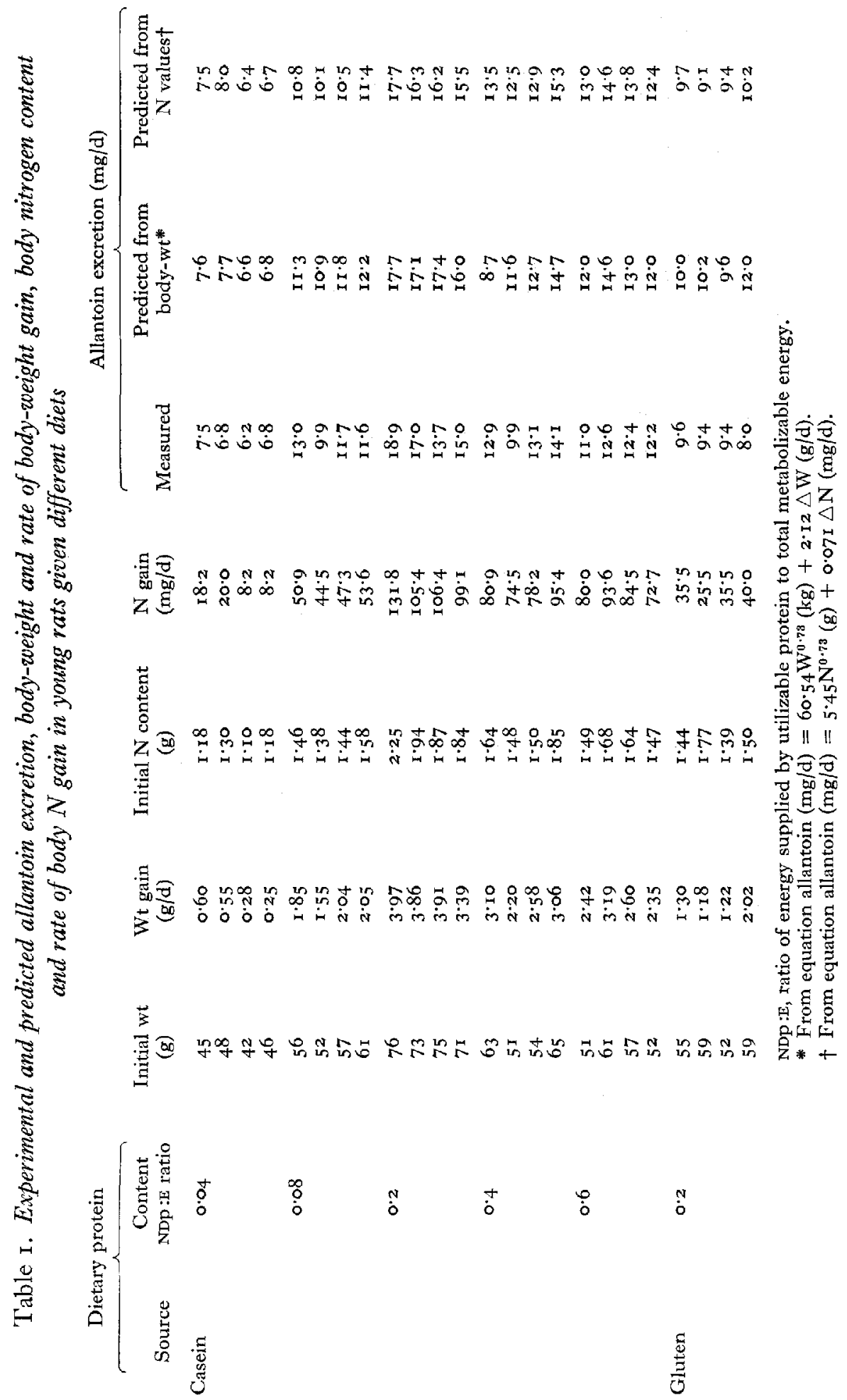




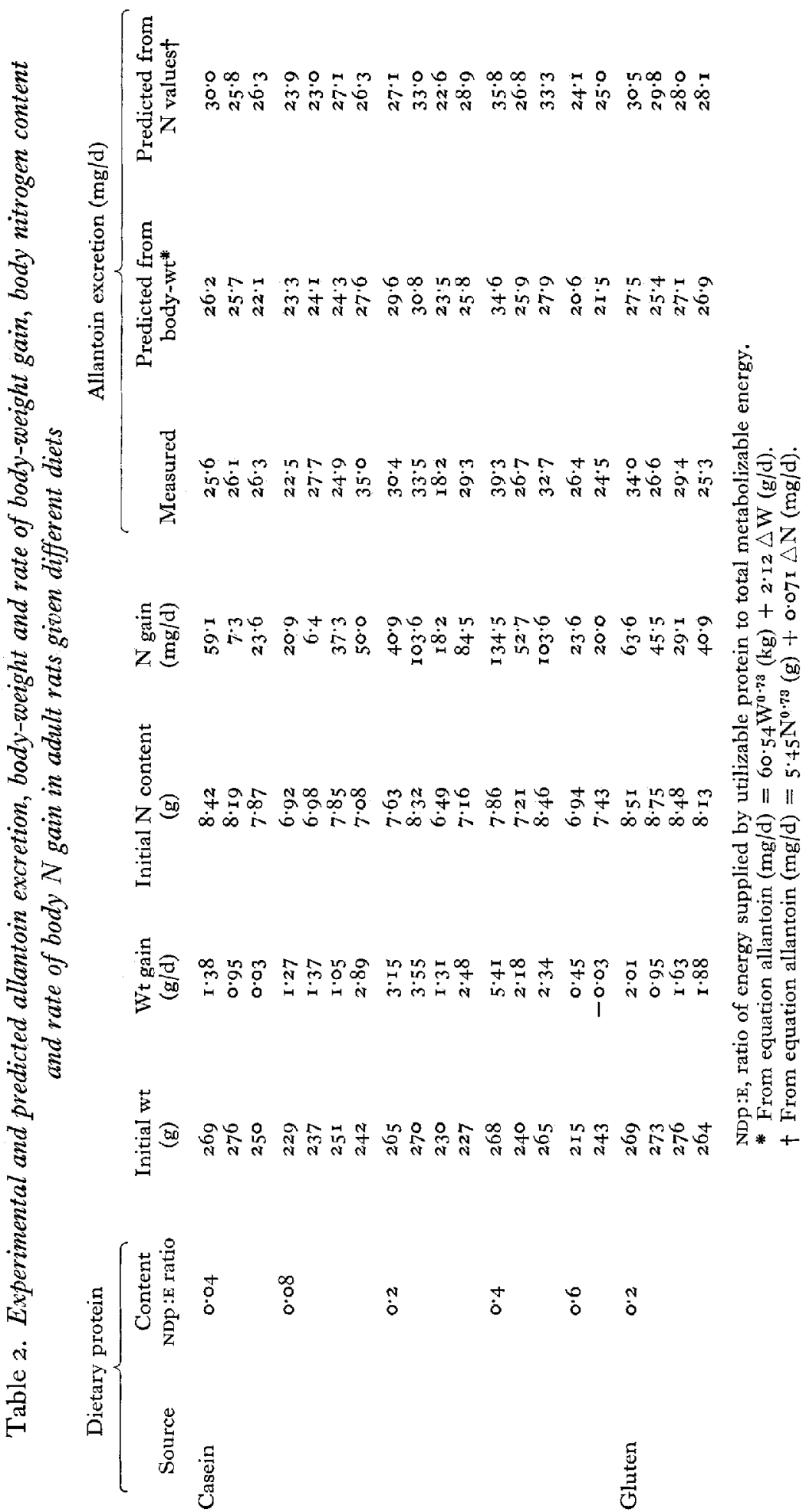




\section{Supplementary trial}

When coprophagy was allowed the faecal output for each rat was $0.2 \mathrm{~g} / \mathrm{d}$; when coprophagy was prevented the faecal output was $0.39 \mathrm{~g} / \mathrm{d}$. In the first group, the mean amount of RNA excreted in the faeces for each rat was $3.7 \mathrm{mg} / \mathrm{d}$ and in the second group, $5.7 \mathrm{mg} / \mathrm{d}$.

These values show that with the non-protein diet, coprophagy is important in relation to both the amount of faeces collected and the amounts of faecal nucleic acids. Under these experimental conditions the rats consumed about half their faeces, in good agreement with results reported elsewhere (Mameesh \& Johnson, I959) for diets lacking some specific nutrient. This was not so in our main trial, in which the animals were supplied with all essential nutrients.

\section{DISCUSSION}

The results of the main trial are valid only when the diet given contained no supply of allantoin precursors (a situation not found with mixed diets) and when coprophagy did not occur.

We attempted to estimate the extent to which coprophagy can influence the results under discussion. Using the values obtained in the supplementary trial, we calculated the maximum effect of the faecal RNA ingested owing to coprophagy ( $1 \cdot 93 \mathrm{mg} / \mathrm{rat}$ per d) on the urinary allantoin excretion, assuming $(a)$ that under our experimental conditions coprophagy was as prevalent as with the non-protein diet, $(b)$ that digestibility and absorption of the ingested nucleic acids were complete, $(c)$ that all the purine bases were quantitatively converted into allantoin, and $(d)$ that all the allantoin produced appeared in the urine. Despite these extreme assumptions the allantoin derived from coprophagy was calculated to be not greater than $0.4 \mathrm{mg} /$ rat per $\mathrm{d}$. This is less than $7 \%$ of the lowest allantoin excretion value (see Table 1 ). Therefore the effect of coprophagy on the urinary allantoin excretion need not be considered.

The relationships presented for the main trial imply that allantoin excretion is independent of the age of the animal, because the values found for young and adult rats fit the same equations: it is also independent of the type of protein consumed, because the values found for the animals given the gluten diet (we used only one level) fit the same expressions as those for the rats receiving casein. Besides, allantoin excretion does not depend directly on the protein concentration in the diet although it does indirectly, since protein concentration is one of the factors affecting weight gain.

At maintenance, that is when $\Delta W$ equals zero, young and adult animals eliminate $60.54 \mathrm{mg}$ allantoin $/ \mathrm{kg}$ body-weight ${ }^{0.73}$ per $\mathrm{d}$, or $5.45 \mathrm{mg}$ allantoin $/ \mathrm{g}$ (body N) ${ }^{0.73}$ per $\mathrm{d}$. This is a reasonable result since $\mathrm{N}$ required for maintenance in various species, expressed per unit of metabolic weight, is constant throughout life (Miller \& Payne, I963). However, it must be remembered that the body composition of younger animals is not the same as that of older ones: the younger ones contain more water and less $\mathrm{N}$ and fat than the older ones. In our experiment at the end of the trial 
immature rats contained $26.0 \pm 0.27 \mathrm{mg} \mathrm{N} / \mathrm{g}$ wet weight and adult animals contained $30.5 \pm 0.25 \mathrm{mg} \mathrm{N} / \mathrm{g}$ wet weight. On the other hand, younger animals have higher protein-turnover rates than older ones (Mende \& Viamonte, I965; Yousef \& Luick, 1969). The significance of these age-dependent differences in relation to the similarity in allantoin excretion is not clear.

This work was partly financed by grant I $7 / 68$ from Comisión Nacional de Investigación Cientifica y Tecnológica (CONICYT), Chile and grant I93/7 I from Comisión de Investigación Científica, Universidad de Chile. 'The authors thank Professor Carlos Martinoya, Department of Physiology and Biophysics, Faculty of Medicine, University of Chile, for statistical advice.

\section{REFERENCES}

Araya, J., Araya, H. \& 'Iagle, M. A. (1971). Archos Biol. Med. exp. 8, R6.

Di Carlo, F. J. \& Schultz, A. S. (I948). Archs Biochem. 17, 293.

Kiriyama, S. \& Ashida, K. (1964). F. Nutr. 82, 127.

Mamcesh, M. S. \& Johnson, B. C. (I959). Proc. Soc. exp. Biol. Med. ror, 467.

Markham, R. (1942). Biochem. F. 36, 790.

Mende, T. J. \& Viamonte, L. M. (I965). Gerontologia II, 208.

Miller, D. S. \& Paync, P. R. (1963). F. theoret. Biol. 5, 398.

Morgan, E. H. \& Hanson, A. (1964). Acta physiol. scand. 60, 164.

Tagle, M. A. \& IJonoso, G. (1965). F. Nutr. 87, 173.

Tagle, M. A. \& Donoso, G. (1967). F. Nutr. 93, 579 .

Young, E. G. \& Conway, C. F. (1942). F. biol. Chem. 142, 839 .

Yousef, M. K. \& Luick, J. R. (1969). Can. F. Physiol. Pharmac, 47, 273. 